Article

\title{
The Father's Role in Child Care: Parental Leave Policies in Lithuania and Sweden
}

\author{
Jolanta Aidukaite * and Donata Telisauskaite-Cekanavice \\ Lithuanian Social Research Centre, 01108 Vilnius, Lithuania; E-Mails: jolanta.aidukaite@lstc.It (J.A.), \\ donata.telisauskaite@gmail.com (D.T.-C.) \\ * Corresponding author
}

Submitted: 26 February 2020 | Accepted: 29 June 2020 | Published: 9 October 2020

\begin{abstract}
This article contributes to the debate on the father's role in child care by looking at two distinct cases of child care policy development: Sweden and Lithuania. The findings show that Sweden continues to embrace the dual-earner-carer model very successfully. Parental leave, including non-transferable father's quota, is very popular among the population. In Lithuania we find the dual-earner model, as there is still more emphasis on the mother's employment than on the father's child care involvement. Based on the experts' views and document analysis, we conclude that in Lithuania the parental leave benefit is increasingly seen as a measure to ensure the family's financial security, but not as an instrument to enhance fatherhood rights. Yet, the state intentionally supports kinship familialism as grandparents are entitled to take parental leave.
\end{abstract}

\section{Keywords}

child care; family policies; Lithuania; parental leave; social policies; Sweden

\section{Issue}

This article is part of the issue "Division of Labour within Families, Work-Life Conflict and Family Policy" edited by Michael Ochsner (FORS Lausanne, Switzerland), Ivett Szalma (Centre for Social Sciences, Hungarian Academy of Sciences Centre of Excellence, Hungary/Corvinus University of Budapest, Hungary) and Judit Takács (Centre for Social Sciences, Hungarian Academy of Sciences Centre of Excellence, Hungary/KWI Essen, Germany).

(C) 2020 by the authors; licensee Cogitatio (Lisbon, Portugal). This article is licensed under a Creative Commons Attribution 4.0 International License (CC BY).

\section{Introduction}

A mother's role as worker and carer has been widely recognised through the provision of various work-family reconciliation policies, while the father's participation in child care is still debated and supported to a lesser degree (Leira, 2002; Ma, Andersson, Duvander, \& Evertsson, 2019; Saraceno, 2013). Previous studies (Bygren \& Duvander, 2006; Hobson, Fahlén, \& Takács, 2011; Ma et al., 2019; Takács, 2019) have shown that in Europe fathers are becoming increasingly actively involved in their parental role. However, their engagement varies considerably among countries, e.g., the Nordic countries are still the leaders with other countries lagging behind. Economic losses in taking parental leave, cultural/societal norms, including childhood socialisation patterns, long work hours and precariousness in the labour market prevent fathers from taking parental leave (Hobson et al., 2011; Ma et al., 2019; Takács, 2019). Yet, workplace characteristics matter, as in the private sector and in male dominated workplaces, where fathers are less likely to take parental leave (Bygren \& Duvander, 2006).

This article seeks to contribute to a further debate on the father's role in child care by looking into two distinct cases of family policy development: Sweden, as a role model in expanding a father's right to child care on the one hand, and Lithuania, as a new EU member with less-developed fathers' rights as a carer on the other. Comparison to Sweden is common in family policy research. Hungary (Hobson et al., 2011), Spain (Hagqvist, Nordenmark, Pérez, Trujillo Alemán, \& Gillander Gådin, 2017), Great Britain (Kaufman \& Almqvist, 2017) and Poland (Suwada, 2017) were compared to Sweden to ex- 
plore how changes in policy affect gendered time use, and how fatherhood is constructed in different socioeconomic settings. This study adopts a similar approach by using Sweden as a reference point for exploring a littleknown case of Lithuania. The Lithuanian case is interesting as it went through numerous reforms in the family policy field over the last 30 years. In recent comparative social policy literature, it is often presented as a highly defamiliarising case of family-support-system development, especially if parental leave and child care policies (from birth to mandatory schooling age) are taken into account (see Javornik, 2014; Javornik \& Kurowska, 2017). However, social policy reforms do not always work in practice as expected, and the outcomes may not necessarily be what was intended (Ferge, 2001). They have to be supported from below in order to make them legitimate (Veenhoven, 2001; Wendt, Mischke, \& Pfeifer, 2011).

Thus, the scope of this article is twofold. On the one hand, we aim (1) to examine the factors that facilitate the expansion of a father's right to be a carer for his children. This is done by re-examining previous literature and drawing conclusions from the analysis of 29 expert interviews conducted specifically for this study. On the other hand, we seek (2) to explore citizens' attitudes towards parental leave policies. This is done by analysing quantitative data collected through original surveys conducted in Lithuania and Sweden. Both aims are interrelated as they help to better understand the father's role in child care in different EU countries. The experts' views and knowledge help to reconstruct the objectives of the child care policies and obstacles encountered by the fathers to take on their child care role. The citizens' satisfaction and attitudes illustrate the actual acceptance of the policies.

Our study is guided by two questions: Which factors/conditions facilitate the expansion of the rights of working fathers to care for their children? How do citizens in Sweden and Lithuania evaluate parental leave policies?

First, we discuss the various family policy models and their intended outcomes for the female labour force participation and gender equality. Second, we present the methodology of the article. Third, we move into a detailed comparative analysis of currently existing child care policies in Sweden and Lithuania. Fourth, based on 29 interviews with experts, we analyse the issues in relation to fathers' involvement in child care. Fifth, we discuss the citizens' satisfaction with parental leave policies to hypothesise how much they can be sustainable in the future. Finally, we offer concluding remarks.

\section{Family Policy, Sweden and Lithuania}

Over the course of welfare state development history in European countries, many welfare state societies directly or indirectly supported the male-breadwinner/familycarer model. The 21st century saw a clear shift to- wards the dual earner, and in some cases also the dual-earner/dual-carer model (Duvander \& Ferrarini, 2013; Saraceno, 2013). In the dual-earner family/gender model, as defined by Korpi (2000), governments seek to increase female labour force participation through policies that support the mother's employment. Central to the dual-earner model are care facilities, available on a continuous basis, for the youngest pre-school children as well as earnings-related maternity and parental leave. The dual-earner/dual-carer model implies that not only do states support both parents' (usually mother's) employment through various welfare provisions, but also encourages the father's participation in child care (Saraceno, 2013). Fathers' participation in child care is encouraged through shared parental leave and/or paternity leave policies specifically designed for a father. It is widely recognised that the Nordic countries are the most advanced in their support of the rights of working fathers to care for their children.

In recent years, researchers developed various typologies of familialisation/defamilialisation to understand variations in family policies across countries and/or also to measure variation at the policy level as both familialising and defamilialising policies can coexist in a single country (Esping-Andersen, 2009; Leitner, 2003; Lohmann \& Zagel, 2016; Saraceno, 2016). Defamilialisation refers to the liberation of the individual (mainly women) from dependencies (financial and caring) on a family relationship. Familialisation refers to the reinforcement of the individual's dependencies in a family relationship (Esping-Andersen, 2009; Leitner, 2003; Lohmann \& Zagel, 2016; Saraceno, 2016; Yin-Nei Cho, 2014). It has been widely agreed that well-developed and widely available public child care services (or provided by the market or voluntary sector) as well as generous paid maternity, parental and paternity leaves, with a strong attachment to the labour market, ensure defamilialisation. Flatrate cash payments that support family care at home and underdeveloped child care services have familialising effects. Paid paternity leave or parental leave, reserved for the exclusive use of fathers, clearly has defamilialising effects as it promotes gender equality in child caring responsibilities and an equal division of unpaid work at home (Leitner, 2003; Lohmann \& Zagel, 2016; Yin-Nei Cho, 2014). However, some authors (Leira, 2002; Saraceno \& Keck, 2011) consider paternity leave to be a form of familialisation of fatherhood, as it helps the father to maintain his familial duties. It increases gender equality in a family, especially in child caring function. For this reason, Saraceno and Keck (2011) have attributed a father's parental leave and paternity leave policies to the supported familialism model. We find concepts of familialisation and defamilialisation useful in analysing the differences and similarities between child care policies in Lithuania and Sweden. However, we do not intend to use them systematically, but rather, we use these concepts to illustrate the dynamics of child care policies in the two countries. 
Sweden is often considered as the most developed example of the dual-earner and dual-carer family model. It should be noted that gender equality has been at the core of family policy formation in all Nordic nations (Grødem, 2017; Haas \& Rostgaard, 2011). Since 1974, Sweden has become the first country in the world that extended the field of family policy to both parents and involved fathers by introducing shared parental leave (Bygren \& Duvander, 2006; Duvander \& Ferrarini, 2013). However:

Non-transferable entitlement to parental leave was first made available to fathers in Nordic nations in 1993, when Norway became the first nation in the world to offer fathers four weeks of father's quota that could not be transferred to mothers. (Haas \& Rostgaard, 2011, p. 180)

In 1995, Sweden switched to a dual-carer family model by introducing one-month compulsory parental leave for a mother and a father (Duvander \& Johansson, 2012). Thus, "the concept of 'caring father' was politically institutionalised well before it was made a policy issue in other countries" (Leira, 2002, p. 11).

Lithuania is an interesting case as it resembles the high female labour force participation, one among the highest in the EU. This could be considered as something that was inherited from the Soviet past. The Soviet state supported mothers' employment through a widespread network of child care facilities. Even if the high female labour force participation was achieved in the Soviet Union, unpaid jobs at home were not monetised. This created great gender inequalities in public and private spheres, as work at home was considered to be the sole female burden. The family policy has gone through dramatic reconfigurations in Lithuania since regaining its independence in the 1990s (for details see Aidukaite, 2006a; Stankuniene, 2001). The reforms' paths have been observed from defamilialism to familialism (1990 until 1996); and from familialism to defamilialism again (1997 and forward), however, with some coexistence (or elements) of familialism at the same time. The Lithuanian family policy was developed inconsistently. The emphasis was placed on financial support, while services were underdeveloped. The meanstested benefits were an important part of the financial support for families in Lithuania (Aidukaite, 2006a, 2016; Žalimienè, 2015). At present, Lithuania has rather generous parental leave policies. A previous study by Javornik (2014) that focused on parental leave and child care policies (from birth to mandatory schooling age), assigned Lithuanian systems as supporting defamilialism since the state seeks to incentivise women's continuous employment and active fatherhood through parental and paternity leave policies and available public child care. However, Lithuanian parental leave policy is not backed up by the secure access to public child care. This creates problems for mothers wanting to return to the labour market after a one-year parental leave (Javornik \& Kurowska, 2017).

In the subsequent discussion, we analyse in detail the child care policies in Sweden and Lithuania looking for similarities and differences. However, before moving into this endeavour, the methodology of the article must be delineated. This is done in the following section.

\section{Methodology}

We ground our methodology on a comparative case study. Comparative case studies encompass the analysis of the differences and similarities across two or more cases that share a common focus. Comparative case studies usually use both qualitative and quantitative data. It is important in comparative case studies to describe each case in depth from the beginning as this enables a successful comparison (Goodrick, 2014). The qualitative data used in this study come from the semi-structured interviews with social policy experts conducted in 2018 in Lithuania and Sweden. Twenty-nine interviews were conducted (14 in Sweden and 15 in Lithuania). In Sweden, the experts interviewed for this study are policy makers working at the Swedish Ministry of Health and Social Affairs, Swedish Social Insurance Agency and leading scholars in the social policy field. In Lithuania, experts interviewed are from the Lithuanian Ministry of Social Security and Labour, Social Insurance Board and leading scholars in the field. We recruited experts through our own knowledge of them in Lithuania. In Sweden, we recruited with the advice of Swedish colleagues working at Stockholm University. We targeted the most leading figures (policy makers, practitioners and scientists) in the family policy field in both countries. The interviews provide rich information to aid in understanding the major problems and challenges in child care policies in the two countries under study as well as to capture conditions that support the father's involvement in child care.

The quantitative data come from the nationwide surveys, which were conducted in two countries in 2018 (December, in Lithuania) and 2019 (January, in Sweden) providing unique information on how citizens evaluate public support to families. The surveys were carried out as part of the project 'Challenges to welfare state systems in Lithuania and Sweden' led by J. Aidukaite and financed by the Research Council of Lithuania. The questions were designed specifically to collect information on the satisfactions and attitudes related to family policy issues in two countries. The questionnaire, in Lithuania, was carried out by the Market and Opinion Research Centre 'Vilmorus.' In Sweden, the identical questionnaire was carried out by NorStat. The multistage probability sample with a random route procedure was used for the survey in both countries. 1,000 respondents were questioned in each country. The response rate was between $28 \%-36 \%$, which is in a normal range. There was no representation bias (distributions regarding some socio-demographics are similar to the popu- 
lation). In Lithuania, the questionnaire was completed through personal, face-to-face interviews at the homes of respondents by trained and supervised interviewers. In Sweden, the survey was carried out online. To capture satisfaction with the parental leave policies, the respondents were asked to evaluate the parental leave policies (parental, paternity and maternity; very good, good, poor, very poor, do not know). The Chi-squared test was used to observe if there are any significant differences in the distribution between men and women in their answers/evaluations.

\section{Child Care Policies in Lithuania and Sweden: A Comparative Analysis}

We began our analysis with the overview of the child care policy arrangements in Lithuania and Sweden, emphasising similarities and differences. They are needed to understand the context in which fathers make their decisions to take parental leave. It is well known that Sweden is a prototype of the social-democratic welfare regime that is characterised by the low levels of poverty and inequality. Yet, an important characteristic of the social-democratic regime is that it places a heavy emphasis on services instead of benefits. On the contrary, Lithuania is among the countries of the EU with the highest income inequalities and the lowest minimum wage (see Aidukaite, 2019), regarded as a postsocialist or hybrid welfare state (Aidukaite, 2006b; Kuitto, 2016), having characteristics of all regimes delineated by Esping-Andersen (1990), with less-developed services, but with heavy reliance on social insurance contributions. These general characteristics are present in the family support systems of two countries. We find significant differences when comparing the provision of child care institutions (nurseries and preschool facilities). According to the OECD data for 2016, the enrolment rate of 3- to 5-year-old children in Sweden was about 96\%, while in Lithuania it was $84 \%$. The differences are much higher if the enrolment rates of children up to 2 years of age are examined. The enrolment rate for Sweden was $46.5 \%$, while for Lithuania it was only $23 \%$, which is lower than that of the EU $(31 \%)$ or OECD (33\%) averages. Nevertheless, in Lithuania and Sweden child care establishment legislation is the same: Children attend the child care facilities/kindergartens until the age of six; public child care services are subsidised by the local governments. However, the right to have a place in the kindergarten is not fully exercised in Lithuania. In Sweden, after a child becomes one year old, he/she has a right to attend the kindergarten and be assigned with a place three months after registration (Swedish Social Insurance Agency, 2018). However, in Lithuania parents, especially in larger cities, have to wait an unlimited time for a place in the kindergarten. Due to lack of public child care facilities, parents are forced to turn to informal care arrangements and the OEDC statistics confirm that. The proportion of children using informal child care (care pro- vided by grandparents or other relatives, neighbours and friends for which the provider does not receive payment) is quite high in Lithuania, which was almost $23 \%$ for 0 - to 2-year-olds and slightly above $30 \%$ for three to five year olds. Informal care in Sweden is negligible, almost absent, comprising 0.4\% (data for 2016; OECD, 2019).

In both countries the universal child allowance is paid to all children irrespective of parents' income. In Sweden, it helps to equalise incomes between parents who raise children and childless individuals. In Lithuania, by introducing the universal child allowance, the government meant to reduce poverty among families with children (for details, see Lithuanian Ministry of Social Security and Labour, 2019; Swedish Social Insurance Agency, 2018). Moreover, parents in Sweden are entitled to up to $25 \%$ shortened working days for raising children until the age of eight, though their income will decrease accordingly (Swedish Social Insurance Agency, 2018). In Lithuania, such an opportunity also exists, but only for parents raising more than one child. One or two off-work days are given depending on the family size and can be used as full non-working days or by shortening working hours (Lithuanian Ministry of Social Security and Labour, 2018).

Overall, the legislation in both countries is rather favourable to parents raising children. In both countries, the universal child allowance is paid, and means-tested benefits are provided; public child care services are subsidised by the local government and additional nonworking days are provided to employed parents with small children.

Let us turn to the parental leave policy, which is of major interest to our study. In Sweden, the maternity, paternity and parental leave policies are merged, while in Lithuania a clear distinction is made and they consist of separate schemes. In Sweden, the only benefit that is eligible to mothers (not both parents) is the pregnancy cash benefit, which is applied and paid for a maximum of 71 days to all women who work in physical or risky jobs. The pregnancy benefit is only available after the Swedish Social Insurance Agency has accepted the work as 'risky,' too physically hard and no temporary change can be made at the workplace. There is also a 2-week paternity leave available to all employed fathers. The pregnancy and the paternity benefits cover up to $80 \%$ of their previous salary (Swedish Social Insurance Agency, 2018).

In Lithuania, all mothers are entitled to maternity leave during their pre-birth and post-birth periods. If a person is not covered by Sickness and Maternity Insurance or does not have sufficient working experience, a pregnancy grant is given (€76, from 2020 increased to $€ 250$ ). Yet, every mother receives a universal child birth grant, which is payable in a lump sum after the child is born (€418, from 2020 paid $€ 429$ ). A maternity benefit for insured mothers is paid for 126 calendar days; the payment period can differ depending on the existing circumstances (e.g., risky physical job). Paternity leave has been enacted by law since July 2006 and currently is paid to fathers for 30 calendar days after child- 
birth and since 1 July 2017 the father can use this period of leave until the child is 3 months old (from 2020 until the child is 12 months old). The ceiling is applied to the paternity benefit. The maximum level of paternity leave benefit due to the ceiling is equal to two national average monthly salaries and the minimal benefit cannot be smaller than $€ 228$ (from 2020 equals to $€ 234$ ). Starting 1 January 2019, the replacement rate for the paternity and maternity benefits is $77.58 \%$ (gross) of the compensated recipient's wages (Lithuanian Ministry of Social Security and Labour, 2019, 2020a, 2020b; MISSOC, 2018; Lithuanian Social Insurance Board, 2019a, 2020).

In Sweden, each parent receives 240 sharable days (480 in total) of parental leave. Both mother and father have an equal part of a non-transferable period of parental leave (90 days each-mother's quota and father's quota), which can be used in parts (months, weeks, days, hours), while the remaining 300 days (from which a 90 day flat rate is paid and does not depend on previous salary) can be shared voluntarily, until the child becomes 12 years old (MISSOC, 2018; Swedish Social Insurance Agency, 2018). Based on interviews discussed in the following section, the Swedish government is considering increasing the number of non-transferable days up to 150, but it has not been enacted yet. While analysing parental leave benefits in Sweden, it is essential to point out that it depends on the previous salary and paid social insurance contributions. The benefit level provided up to 390 days is relatively high-up to $80 \%$ of previously received salary, the minimum rate- $€ 24.30$ per day. Sweden has a fixed 'ceiling' for parental leave benefit-it cannot be higher than $€ 3,606.22$ per month. The remaining 90 days of parental leave are paid at an equal flat rate of $€ 17.50$ per day regardless of past income. Those parents who are unemployed receive a benefit of up to $€ 24.30$. The employers are actively involved in providing various family benefits, for instance, employers on their own initiative, based on collective agreements, are able to compensate the part (about 10\%) of employees' previous income who are on parental leave (MISSOC, 2018; Swedish Social Insurance Agency, 2018).

Parental leave in Lithuania can be taken by a father or a mother. From 1 April 2018, one of the grandparents can also take a parental leave, if both parents want to come back to work and the grandparent is covered by the social insurance. The family is able to choose how long they want to receive the parental leave benefitone or two years. According to new amendments implemented in January 2019, if a parent (or foster parent) chooses to receive a benefit until the child is one year old, he/she is paid $77.58 \%$ (gross) of the compensated recipient's wages. If one of the parents (or foster parents) chooses to receive the benefit until the child is two years old, he/she is paid $54.31 \%$ (gross) until the child is one year old, and later, until the child is two years old, $31.03 \%$ (gross) of the compensated recipient's wages. During the second year the father or mother receiving the benefit has the ability to work and receive the child care benefit at the same time (Lithuanian Social Insurance Board, 2019). If two or more children are born, compensation increases according to the legislation. Both a 'ceiling' and 'floor' are applied to the parental leave benefit (Lithuanian Ministry of Social Security and Labour, 2019; MISSOC, 2018).

To sum up, according to legislation the Swedish and Lithuanian parental leave systems show signs of similarities and differences. The major difference is, in Sweden the more active the father's involvement is in child care, he can receive three months of non-transferable parental leave. The Swedish system also offers a higher flexibility as the parental leave can be utilised until the child's 12th birthday. The father's role in child care is obviously less pronounced in Lithuania as it is only one month of the entitlement for a father. But the father has an opportunity to take parental leave in the second or the first year.

\section{Analysis of Interviews of Experts in Lithuania and Sweden}

Before starting our analysis of interviews of experts, it is important to look at some statistical data on the fathers' parental leave. According to the latest OECD data for 2016, the male share of recipients of parental leave in Sweden was $45.3 \%$, while in Lithuania it is $21.6 \%$. The OECD average was $18 \%$. In Sweden, the father's quota, which was introduced in 1995, became popular, and helped to gradually increase the proportion of fathers taking longer parental leaves (Ma et al., 2019). According to the Lithuanian Social Insurance Board (2019b) statistics, the number of fathers taking parental leave increased from 3,300 who received it in 2009 to 10,100 who received it in 2018. Let us examine the experts' views on fathers' behaviour.

The majority of experts interviewed stressed that in Lithuania fathers choose parental leave purely due to the family's financial interests: "Women usually take parental leave because women still receive lower salaries than men, so men work to support their families" (LT expert, Lithuanian Social Insurance Board). Families evaluate their financial options and calculate for which parent it is more advantageous to use parental leave so the family would not endure income loss. Informants also observed that fathers often choose to take a second year of parental leave:

For the first year, surely, mothers use the child care leave, while during the second year, it is transferred to fathers, because they get bigger salaries, and if you read the legislation, it is also not obligatory to evaluate income, fathers simply receive $40 \%$ of their previous salary. (LT expert, Lithuanian Social Insurance Board)

In Lithuania a mother is covered by social insurance until the child turns three, if she is not working. However, 
this affects her future pension benefit as she is only insured with minimum wage contributions. Since the gender wage gap still exists, the men often receive a higher salary than women, it is financially beneficial for a father to go on parental leave during the second year. This is also supported by previous studies. Studies (Braziene \& Vysniauskiene, 2019; Šarlauskas \& Telešienè, 2014) showed that the majority of families in Lithuania chose to stay on parental leave up to two years. These are mainly mothers (about 70\%-80\%), who take two-year parental leave. Few mothers (about 10\%) and fathers (less than 5\%) took the one-year parental leave in 2013. The pattern has been identified in Lithuania that parental leave for a second year was increasingly taken by the fathers. Their numbers have increased from $5 \%$ up to $20 \%$ during the period from January 2012 through August 2013. In most of these cases the mother stayed at home and engaged in full time home care, while the father engaged in full time employment and additionally received a parental benefit. This situation, as stressed by Šarlauskas and Telešienè (2014), supports familialism, increases the mother's financial dependency upon her husband and does not contribute to gender equality within the family.

It can be stated that in Lithuania the parental leave benefit is increasingly seen as a tool to ensure the family's financial security, but not as a key to enhance fatherhood rights. Nevertheless, the Lithuanian experts viewed parental leave policy in a positive way. This can be illustrated by the quote: "The parental leave system is probably one of the best in Europe, taking into account a long duration and the possibility to share it between parents" (LT expert, Lithuanian Ministry of Social Security and Labour).

The economic incentives of taking parental leave were also emphasised in Sweden, however, to a lesser extent and from a different perspective. Sweden is also facing difficulties, despite the continuing policy of gender equality throughout the years. Parental leave is still largely used by women ( $40 \%$ male vs. $60 \%$ female; Swedish Social Insurance Agency, 2017), one reason being a gender pay gap. The other issue concerns the parental benefit size. The low-income fathers are not inclined to take parental leave as it reduces their income considerably. This means that gender equality is more feasible among higher income earners as middle- and upper-class fathers are more inclined to take parental leave than lower income fathers. Many of the experts worried that fathers with low income or outside of the labour market, without social insurance coverage, use parental leave to a lesser extent:

Well fathers who do not have a job and are outside the labour market they do not use the parental leave to the same extent. So they are outside the social insurance system and they are outside the labour market, so they become marginalised in that way. (SE expert, scientist)
These are often people with an immigrant background, working on a secondary labour market. The migrant families, especially those newly arrived, support the traditional family model of a single male breadwinner, which contradicts the Swedish dual-earner-carer model. These findings were also supported by the previous study (Ma et al., 2019), which showed that better-educated, living in metropolitan areas and surrounding suburbs, as well as Swedish-born fathers used parental leave more than young fathers, low-income earners and foreignborn fathers. Other studies (Grødem, 2017; Sainsbury, 2018) also pointed out that immigrant parents often have different behaviour when it comes to child care choices than Swedish-born parents.

However, in Sweden the experts were much more concerned about the behavioural aspects of taking parental leave than its financial benefits. In Sweden, informants emphasised that the major reason fathers choose to use parental leave is their intention to establish a stronger relationship with their children and family. There is a strong awareness among policy makers in Sweden that a father's involvement in child care makes family relationships healthier, and in this sense, it makes families stronger in the long run. Additionally, routinely sharing family duties can help give each parent an equal chance to successfully return to the labour market and maintain their professional competencies. Based on the experts' views, it is possible to state that 'daddy's leave' has become entrenched into the national culture, it is a norm in Sweden and even gives a sense of national pride. Cederström (2019) also states that today, father's leave has become a norm in the Nordic countries. This is illustrated by the quotes: "I think if we want to talk about something that has been successful in the Swedish family policy it is really this engagement of fathers in parental leave because they are using a lot of leave" (SE expert, scientist). The Swedish welfare state is known for well-developed services that allow mothers (parents) to engage in full time (or part-time) jobs and have children. Yet, gender equality is the cornerstone of family policy in Sweden. This is not going to change or go away. Experts see the day care, parental leave and father leave as the tools, ensuring gender equality and they are untouchable:

Well, I think that certain things are untouchable. Nobody could take away the day care, it is just like a sacred cow. That is also true of parental leave and father leave. I do not think anybody is ever going to touch that. (SE expert, scientist)

The experts are well aware of the positive outcomes that shared parental leave provides: fathers become more empowered, they create their own fathers' networks and support groups; if they become involved in the child's life during early childhood, they would be more likely to continue being involved later on. However, despite these positive developments, the experts emphasised 
the drawbacks. The labour division within the family is still unequal and women still do more of the household work.

Hence, Swedish experts were well aware of the positive outcomes that the father's involvement in child care can generate for family stability and gender equality. The Lithuanian experts were more concerned with the workfamily reconciliation policies that help mothers engage in full employment; less concern was expressed about the father's responsibility in child care and unequal household work at home. Gender equality was understood as policies facilitating women's integration into the labour market, but not as much as the father's involvement in child care.

All experts in Lithuania mentioned that the main obstacle interfering with family and work reconciliation in Lithuania is a shortage of preschool facilities:

It is important to have well-developed services for families with small children to help both parents to work and not to fall out of the labour market. We really need to develop services; it is not good when parents are out of the labour market for two or three years simply because they have not enough income to hire a nanny and have nowhere to leave their little child. (LT expert, Lithuanian Ministry of Social Security and Labour)

Due to a lack of child care facilities and their short working hours, the grandparents helping with child care is common in Lithuania. It is possible to say that in Lithuania the particular type of familialism, which we call the kinship familialism, is entrenched in child care. The government is keen to support this kind of familialism, as it is possible, according to the legislation, for the grandparents to take parental leave. According to the latest data received from the Lithuanian Social Insurance Board (personal communication), in 2018, 503 grandparents took parental leave in Lithuania.

The Lithuanian case shows that cultural norms, such as kinship support, can be transferred to the family policy legislation and can be formalised. The Swedish case shows the opposite, that the family policy legislation forms cultural practices. Specifically, the enactment of non-transferable parental leave can motivate fathers to take care of their children. Swedish experts noticed a tendency that policy legislation is the key factor that encourages fathers to choose parental leave:

We used to have a law where non-transferable parental leave was 30 days, and what do you think? Fathers used exactly one month. Now non-transferable parental leave is 90 days, and as I know some statistics, fathers are going on parental leave exactly 90 days. (SE expert, Swedish Social Insurance Agency)

Fathers choose the parental leave duration, which is specified in legislation. Fathers, by their own initiative, rarely choose to use a longer period. According to the Swedish Social Insurance Agency (2018), only a small percentage of fathers chose parental leave for more than 90 days. However, the overall trend is that fathers increasingly take a longer parental leave (see Ma et al., 2019).

The case of Lithuania shows that the legislation can create unintended practices such as fathers going on parental leave during the second year of child care leave and receiving a parental benefit and a full time wage, while mothers were staying at home as full time carers or grandparents taking parental leave. Thus, the country's family policy legislation combined with and the economic situation of many families in Lithuania have produced a particular practice for the fathers to take parental leave.

Despite some differences revealed between the practices of taking parental leave in two countries, we also find similarities. There is an awareness among policy makers in both countries that the prevailing gender role stereotypes in a society and employers' attitudes are important for helping fathers decide whether or not to take parental leave. Lithuanian society is still combating gender stereotypes (societal and employers') regarding parental leave policies: "Currently we are still facing stigmatisation of fathers who take parental leave, which is equally encountered by mothers, who do not want to use child care leave.... think, that it is a Lithuanian culture problem" (LT expert, Lithuanian Ministry of Social Security and Labour).

The family policy legislation supports fatherhood and labour laws forbid any form of discrimination in the work environment. However, changing cultural norms and public opinion can be much harder.

While Lithuania is still striving to combat gender stereotypes in child care, in Sweden the father's leave has already become a norm. The father could even be stigmatised if he does not go on parental leave. As one expert stated: "It would be very strange if your colleague at work did not go on leave. He would get all the questions of 'why, what is wrong'?"' (SE expert, scientist). The employers are often present in the negotiations on parental leave policies together with the policy makers and trade union representatives. In Sweden, the generous parental leave policy is viewed as a tool to attract labour to their companies, not as a penalty imposed upon employers.

Based on the interview analysis, we assume that in Sweden parental leave policy should be widely accepted by the population and evaluated very positively. In Lithuania, the parental leave policies should also be evaluated quite positively. However, the evaluations are expected to be lower than in Sweden.

\section{The Subjective Evaluation of the Parental Leave Policies}

Having discussed the experts' knowledge, in this section, we turn to people's attitudes and subjective evaluations of the parental leave policies. The acceptance of the pol- 
icy by evaluating it as 'very good' or 'good' shows the success of the social policy reform.

Figure 1 illustrates the subjective evaluations of the parental leave policies that include parental, paternity and maternity leaves in Lithuania, while in Sweden the parental leave embraces all policies, including nontransferable parental leave. As noted, in Sweden, there is no clear distinction between the maternity and paternity policies, they are merged into the parental leave scheme, while in Lithuania a clear distinction exists among maternity, paternity and paternity policies. The respondents' evaluations support the experts' views. In Sweden, the parental leave policy is a great success and a national pride. More than half (54\%) of all respondents evaluated the parental leave policy as 'very good' and almost 31\% reported it as 'good.' This is more than $80 \%$ of all respondents. Those who have evaluated it as 'poor' or 'very poor' comprise just one percent. There were no significant gender differences in evaluations $(p=0.222>0.05$ Pearson Chi-Square), showing that both genders are equally satisfied with the parental leave policy.

In Lithuania, the evaluations are not as good as in Sweden, but still half of the respondents evaluated the parental leave policies (about $41 \%-45 \%$ as 'good' and about $6 \%-10 \%$ as 'very good' for parental, paternity and maternity policies) positively. One quarter of all respondents evaluated it as 'fair' and a small group, about 6\% for each three policies, evaluated it as 'poor' or 'very poor.' These evaluations, to some extent, contradict the views of the experts as many of them evaluated the parental leave policies as very good, and being among the best in Europe. The citizens' views show that improvements are needed if the Lithuanian government wants to be among the leading nations having the best parental leave policies in Europe. The major reason for the poorer evaluations than in Sweden can be the lack of complementarities, both on the policy level and in the national socioeconomic conditions. On the policy level, the lack of child care facilities, which was mentioned by the experts, can minimise the positive evaluations. On the national level, the increase in the minimum wage is needed as well as other macroeconomic policies allowing an increase in the average wage.

\section{Conclusion}

This article contributed to the debate on the father's role in child care by looking at two distinct cases of child care policy development: Sweden and Lithuania. We employed both qualitative (expert interviews) and quantitative (nationwide survey) data to reach our aims. The experts' views and knowledge helped to reconstruct the objectives of the child care policies and obstacles encountered by the fathers in taking their child care role. The citizens' satisfaction and attitudes illustrated the actual acceptance of the policies by the parents/citizens and how it could progress in a future.

The findings show that Sweden continues to very successfully embrace the dual-earner-carer family/gender policy model. The parental leave, including non-transferable father's quota, is very popular among the population. It gives a sense of pride and ensures gender equality. In Lithuania we find a dual-earner model, as there is still more emphasis on the mother's employment than on the father's child care involvement. The efforts to facilitate fatherhood are gradually increasing through the paternity leave policy that was implemented in 2006 and already gained support among the Lithuanian population.

Sweden maintains defamilialism in its child care policy and this is not going to change in the future. Contrarily, the shared parental leave quota might be extended from three to four months in the future, as revealed by experts' interviews.

In Lithuania we find a particular type of familialism, which we call kinship familialism. The state supports both parents' active involvement in the labour mar-

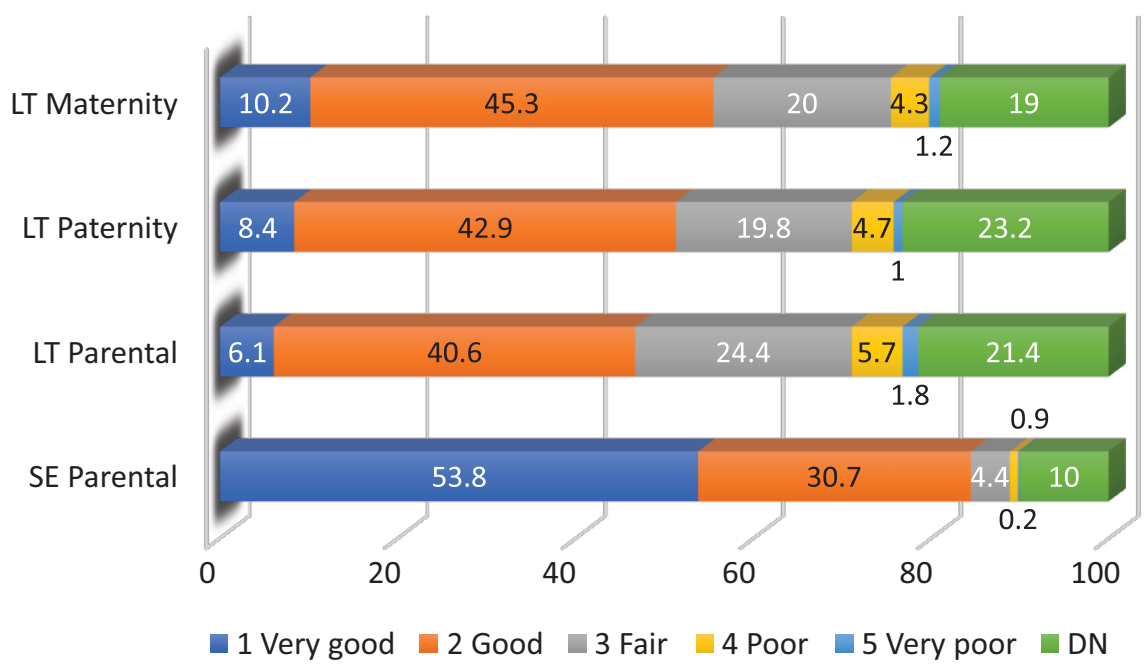

Figure 1. Subjective evaluation of the parental leave policies in Sweden (January 2019; $N=1,000$ ) and Lithuania (December 2018; $N=1,000$ ). 
ket through relatively generous parental leave policies. However, it lacks a more coherent and broader view on family policy by not providing complementarities to parental leave policies to make them more effectively exercised. The lack of child care facilities and the possibility of taking parental leave for two years, while having the possibility of working at the same time, in some cases entrenches family dependency, although the policy itself is meant to increase defamilialism. Yet, the state intentionally supports kinship familialism as grandparents are entitled to take parental leave. Based on the experts' views and document analysis, we conclude that in Lithuania the parental leave benefit is increasingly seen as a measure to ensure the family's financial security, but not as an instrument to enhance fatherhood rights.

The analysis revealed three major reasons facilitating the father's involvement in child care. First of all, it is mainly the financial reason that was expressed by the Lithuanian experts, but also important in the Swedish case, particularly for low income fathers. Second, the cultural or moral reason is the desire to care for a child and to strengthen father-child relationships. In this situation, the positive attitudes of employers and society are needed, which can combat gender stereotypes in child care. The third one, and probably the most important one, is the legislation that encourages or even forces the fathers to go on parental leave.

The country's family policy legislation, the economic situation of many families in Lithuania and the lack of child care facilities in combination, have produced a particular practice for the fathers to take parental leave; namely, the father goes on parental leave, but works full time in practice and the mother stays at home.

This study contributes to the previous literature at least in three important ways. First, it enhances our intimate knowledge of Swedish and Lithuanian parental leave policy development from a comparative perspective. Second, it highlights the factors that facilitate the father's rights to child care. Third, it contributes to a better understanding of how the country's family policy legislation interacts with the socioeconomic, attitudinal and cultural environment in producing intended or unintended practices. Future studies should focus on parents' experiences in taking parental leave in order to better understand the reasons behind the embraced practices.

\section{Acknowledgments}

This study is financed by the Research Council of Lithuania under the project 'Challenges to welfare state systems in Lithuania and Sweden,' grant No. S-MIP17-130. The project is carried out in cooperation with the Department of Sociology, Stockholm University. The authors would like to acknowledge the project team members Kristina Senkuviene, Teodoras Medaiskis and Šarūnas Eirošius who also contributed to the performance and/or transcription of expert interviews analysed in this article. We also want to thank our coopera- tive partners in Sweden (Livia Olah, Gerda Neyer, Sunnee Billingsley) and Barbara Hobson for providing support in developing the questionnaire for the quantitative survey and/or providing support for reaching experts in Sweden. The authors would like to thank the Academic Editors of this thematic issue and anonymous reviewers for useful comments. The earliest versions of the draft of this article was presented at the annual ISA RC19 'Poverty, social welfare and social policy" conference on 28-30 August 2019, University of Manheim, Germany and at the Sociology Seminar on 2 of October 2019, Stockholm University, Sweden. We would like to thank all who commented on it. The special thanks go to all experts in Sweden and Lithuania who agreed to be interviewed for this study and shared their invaluable opinions and knowledge with us.

\section{Conflict of Interests}

The authors declare no conflict of interests.

\section{References}

Aidukaite, J. (2006a). Reforming family policy in the Baltic states: The views of the elites. Communist and PostCommunist Studies, 39(1), 1-23.

Aidukaite, J. (2006b). The formation of social insurance institutions of the Baltic states in the postsocialist era. Journal of European Social Policy, 16(3), 259-270.

Aidukaite, J. (2016). Support to families with children in the Baltic States: Pathways of expansion and retrenchment from 2004 till 2016. Paper presented at the workshop 'Baltic states after the crisis? The transformation of welfare systems and social problems,' Vilnius, Lithuania.

Aidukaite, J. (2019). The welfare systems of the Baltic States following the recent financial crisis of 2008/2010: Expansion or retrenchment? Journal of Baltic Studies, 50(1), 39-58.

Braziene, R., \& Vysniauskiene, S. (2019). Paid leave policies and gender inequalities in Lithuania: An analysis of structure and choices of benefits recipients. Paper presented at the workshop 'Challenges to the welfare state systems in the Baltic and Nordic countries,' Vilnius, Lithuania.

Bygren, M., \& Duvander, A. Z. (2006). Parents' workplace situation and fathers' parental leave use. Journal of Marriage and Family, 68, 363-372.

Cederström, C. (2019). State of Nordic fathers. Copenhagen: Nordic Council of Ministers.

Duvander, A. Z., \& Ferrarini, T. (2013). Sweden's family policy under change: Past, present, future (Working Paper 2013: 8). Stockholm: SPaDE.

Duvander, A. Z., \& Johansson, M. (2012). What are the effects of reforms promoting father's parental leave use? Journal of European Social Policy, 22(3), 319-330. 
Esping-Andersen, G. (1990). The three worlds of welfare capitalism. Cambridge: Polity Press.

Esping-Andersen, G. (2009). The incomplete revolution: Adapting to women's new roles. Cambridge: Polity Press.

Ferge, Z. (2001). European integration and the reform of social security in the accession countries. European Journal of Social Quality, 3(1/2), 9-25.

Goodrick, D. (2014). Comparative case studies: Methodological briefs. New York, NY: UNICEF Office of Research.

Grødem, A. S. (2017). Family-oriented policies in Scandinavia and the challenge of immigration. Journal of European Social Policy, 27(1), 77-89.

Haas, L., \& Rostgaard, T. (2011). Fathers' rights to paid parental leave in the Nordic countries: consequences for the gendered division of leave. Community, Work \& Family, 14(2), 177-195.

Hagqvist, E., Nordenmark, M., Pérez, G., Trujillo Alemán, S., \& Gillander Gådin, K. (2017). Parental leave policies and time use for mothers and fathers: A case study of Spain and Sweden. Society, Health \& Vulnerability, 8, 1-11.

Hobson, B., Fahlén, S., \& Takács, J. (2011). Agency and capabilities to achieve a work-life balance: A comparison of Sweden and Hungary. Social Politics, 18(2), 168-198.

Javornik, J. (2014). Measuring State de-familialism: Contesting post-socialist exceptionalism. Journal of European Social Policy, 24(3), 240-257.

Javornik, J., \& Kurowska, A. (2017). Work and care opportunities under different parental leave systems: Gender and class inequalities in northern Europe. Social Policy Administration, 51(4), 617-637.

Kaufman, G., \& Almqvist, A.-L. (2017). The role of partners and workplaces in British and Swedish men's parental leave decisions. Men and Masculinities, 20(5), 533-551.

Korpi, W. (2000). Faces of inequality: Gender, class, and patterns of inequalities in different types of welfare states. Social Politics International Studies in Gender, State and Society, 7(2), 127-192.

Kuitto, K. (2016). Post-communist welfare states in European context patterns of welfare policies in central and eastern Europe. Cheltenham: Edward Elgar Publishing.

Leira, A. (2002). Working parents and the welfare state: Family change and policy reform in Scandinavia. New York, NY: Cambridge University Press.

Leitner, S. (2003). Varieties of familialism: The caring function of the family in comparative perspective. European Societies, 5(4), 353-375.

Lithuanian Ministry of Social Security and Labour. (2018). Kada ir kam priklauso mamadieniai ir tèvadieniai? [When and to whom do mothers and fathers' days belong?]. Lithuanian Ministry of Social Security and Labour. Retrieved from https://socmin.Irv.lt/ It/naujienos/mamadieniai-ir-tevadieniai-priklauso- abiems-tevams

Lithuanian Ministry of Social Security and Labour. (2019). Socialinè parama šeimoms ir vaikams [Social support for families and children]. Lithuanian Ministry of Social Security and Labour. Retrieved from https://socmin.Irv.lt/It/veiklos-sritys/seima-irvaikai/socialine-parama-seimoms-ir-vaikams

Lithuanian Ministry of Social Security and Labour. (2020a). Išmokos vaikams (išmokos kūdikio besilaukiančioms moterims, vaikus auginantiems tèvams) [Child benefits (benefits for women who have children, parents raising children)]. Lithuanian Ministry of Social Security and Labour. Retrieved from https://socmin.Irv.lt/lt/veiklos-sritys/seima-irvaikai/socialine-parama-seimoms-ir-vaikams/ ismokos-vaikams-ismokos-kudikio-besilaukianciomsmoterims-vaikus-auginantiems-tevams

Lithuanian Ministry of Social Security and Labour. (2020b). Tẻvystès išmoka [Paternity benefit]. Lithuanian Ministry of Social Security and Labour. Retrieved from https://socmin.Irv.lt/lt/veiklos-sritys/ socialinis-draudimas/socialinio-draudimo-ismokos/ valstybinio-socialinio-draudimo-ismokos/tevystesismoka

Lithuanian Social Insurance Board. (2019a). Pensijos ir išmokos [Pensions and benefits]. Lithuanian Social Insurance Board. Retrieved from https://www.sodra. It/It/pensijos-ir-ismokos

Lithuanian Social Insurance Board. (2019b). Ligos ir motinystès išmokų atvejai (gavèjai) [Cases of sickness and maternity benefits (recipients)]. Lithuanian Social Insurance Board. Retrieved from https://atvira. sodra.lt/lt-eur

Lithuanian Social Insurance Board. (2020). Pagrindiniai socialiniai rodikliai [Key social indicators]. Lithuanian Social Insurance Board. Retrieved from https://www.sodra.It/It/situacijos/statistika/ pagrindiniai-socialiniai-rodikliai

Lohmann, H., \& Zagel, H. (2016). Family policy in comparative perspective: The concepts and measurement of familization and defamilization. Journal of European Social Policy, 26(1), 48-65.

Ma, L., Andersson, G., Duvander, A. Z., \& Evertsson, M. (2019). Fathers' uptake of parental leave: Forerunners and laggards in Sweden, 1993-2010. Journal of Social Policy, 49(2), 361-381. https://doi.org/ $10.1017 /$ S0047279419000230

MISSOC. (2018). Comparative tables database. MISSOC. Retrieved from https://www.missoc.org/missocdatabase/comparative-tables

OECD. (2019). OECD family data base. OECD. Retrieved from http://www.oecd.org/social/family/ database.htm

Sainsbury, D. (2018). Policy constructions, immigrants' social rights and gender: The case of Swedish child care policies. Journal of European Social Policy, 1(15), 213-227.

Saraceno, C. (2013). Family policies. In B. Greve (Ed.), 
The Routledge handbook of the welfare state (pp. 381-400). London and New York, NY: Routledge Taylor and Francis Group.

Saraceno, C. (2016). Varieties of familialism: Comparing four southern European and East Asian welfare regimes. Journal of European Social Policy, 26(4), 314-326.

Saraceno, C., \& Keck, W. (2011). Towards an integrated approach for the analysis of gender equity in policies supporting paid work and care responsibilities. Demographic Research, 25(11), 371-406.

Šarlauskas, T., \& Telešienè, A. (2014). The regulation of state social insurance: Structure and choices of beneficiaries. Public Policy and Administration, 13(1), 95-108.

Stankuniene, V. (2001). Family policy of Lithuania: A changing strategy. Paper presented at the European Population Conference 2001, Helsinki, Finland.

Suwada, K. (2017). Men, fathering and the gender trap: Sweden and Poland compared. Cham: Palgrave Macmillan.

Swedish Social Insurance Agency. (2017). Social insurance in figures 2017. Swedish Social Insurance Agency. Retrieved from https://www. forsakringskassan.se/wps/wcm/connect/6fa0e434a212-4e6b-8c8d-5d7a498a253d/socialforsakringen-
siffror-2017-engelsk.pdf?MOD=AJPERES\&CVID=

Swedish Social Insurance Agency. (2018). Parental benefits. Swedish Social Insurance Agency. Retrieved from https://www.forsakringskassan.se/privatpers/ foralder/nar_barnet_ar_fott/foraldrapenning

Takács, J. (2019). How involved are involved fathers in Hungary? Exploring caring masculinities in a postsocialist context. Families Relationships and Societies, 23, 1-16.

Veenhoven, R. (2001). Why social policy needs subjective indicators: Research unit social structure and social reporting (Report FS III 01-404). Berlin: Social Science Research Center.

Wendt, C., Mischke, M., \& Pfeifer, M. (2011). Welfare states and public opinion: Perceptions of healthcare systems, family policy and benefits for the unemployed and poor in Europe. Cheltenham: Edward Elgar Publishing.

Yin-Nei Cho, E. (2014). Defamilization typology reexamined: Re-measuring the economic independence of women in welfare States. Journal of European Social Policy, 24(5), 442-454.

Žalimienè, L. (2015). Family support policy in Lithuania: Can we identify paradigmatic changes in the period 1996-2013? Tiltai, 70(1), 39-61.

\section{About the Authors}

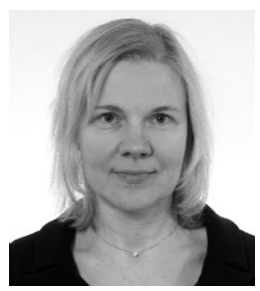

Jolanta Aidukaite (PhD in Sociology from Stockholm University) is a Chief Researcher at the Lithuanian Social Research Centre. Her main research interests are focused on welfare state, social policy, family policy, housing policy and urban community mobilisation. She recently edited a special issue of Journal of Baltic Studies "Baltic States after the Crisis? The Transformation of the Welfare System and Social Problems" (2019).

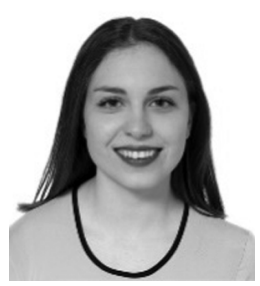

Donata Telisauskaite-Cekanavice has held an internship at the Lithuanian Social Research Centre in 2018 (July-August) financed by the European Social Fund grant No. 09.3.3-LMT-K-712-09-0193. She works at the Lithuanian Ministry of Social Security and Labour. She holds a master's degree in Social Policy from Vilnius University. 